tech. u. Maschinenb., 1958-5, Jg. 48, Ht. 5, S. 270 276, 因 13]製品の仕上面の視覚による検査につき 述べた論交でまず人間の視覚の鋭敏性とその一般的性 質を説明し，この視覚にたよる検查の熊をドイツお よびアメリカに例をとって批判し，人間はいかなる機 構によって視覚によって検査を行い得るかの原理をき わめ，これを容易に行わせるための各種の補助的措置 および装置を説明し，次にこの視覚による主観的の検 查の内蔵する各種の欠点から考えて，これを機峨化さ れた答観的の検查法には，いかにして䎐向すべきかを 示唆している. 最もひん笅に生じる仕上表面の久陷は 仕上面より反射して来る光線を目に受けて，その不連 続性や光量不足性によって指摘するのであるが，これ は光電池を巧みに組合わせることによって機栈化が可 能であり，大量生産のばあいの閒断なく送られて来る 製品の視賞検查もこれによって能率的に代行せしめる ことができる。

$621.753: 531.713$

†[617] $6000 \mathrm{~mm}$ までの測長能力のある測長機〔G. Dietrich., Werkstatistech. u. Maschinenb., 19585, Jg. 48, Ht. 5, S. $276 \sim 281$, 図 9, 表 1] 大形 㙨械の製造のばあいに，長さのとくに長い部品また は, 機械部分の精密測定機器は比較的不完全のまま放 置されていたが，本論文はこれについて、ジーメンス・ シェッケルトの発電機工場で使用せられている 6000 $\mathrm{mm}$ の長さを正確に測定しうる測長機械の解説であ る.この㙨械は他に類例がなく，設置については相当 に決断力を必要としたが，この機械により精密な測定 を行うことが可能になった。

構造は水平調整式のベッドの全長にデシメートル目 盛の物指を置き，スライドによって被測定物を移動さ せる.一つのデシメートル目盛に二重像式顕微鏡の焦 点を合わせ，スパイラル顕微鏡でセンチメータ，ミり メータを読む. カールツァイスの測長機の愦差と本機 の愦差との比較が被測定物の長さについて表記してあ る.

[近藤康治]

\section{$621.753: 531.71$}

†[618]工場現場における長物の正確測定法〔H. Schmidt, Werkstattstech. u. Maschinenb., 1958-6, Jg. 48, Ht. 6, S. 309 315, 図 13] 機械製作現場 における諸作業の中で，大形構造物ならびに部分品を 精密に長さを測定することは各工場とも非常に困難を 感じている項目である. 本論文はこの難問に対して種 ふの参考になる解決法を示唆した論文であり，あまり 高洒な科学的装置を使用せず，現場にあるあり合わせ の計器を組合わさて用いるところに特長がある。とく に ISA の精度規格が旧来の $500 \mathrm{~mm}$ より搪大され $10000 \mathrm{~mm}$ までの長さの測定が問題になって来な現状 を念頭に置いて記述してある。まずイギリス，イタリ ア, ドイツの各国の長物の測定用の器具々規格, 許容 愦差を略述し，具体的な則定実例にはいり，ブロック ゲージ連結法および特殊長尺物指を利用した長物測定 装置,棒状マイクロメータに延長部を設けた測定装置, 既設のロータリミルを利用した大物の内径測定法, ブ ロックゲージとテストインジケータを結合した簡易測 長具, 1000 ～ $1500 \mathrm{~mm}$ の測長能力をも自重わずか に $12 \mathrm{~kg}$ のここ形マイクロメータ，等を述べ温度によ
る䛊美の修正のために正確に表面温度定測定する可搬 式電気温度計を推奨している. 〔近藤 康治〕

\subsection{2 .4}

[619]慣性を調節できるテンプ (L. Defossez, J. Swiss Watch \& Jewelry, 1958-10, Vol. 83, No. 5, p. 651 655, 図 5]携㗆時計の歩菨の調整は普通緩 急針によって行われる。緩急針とひげとの接点はひげ の固定端ではなく，テンプが回䎐するとわずかではあ るが移動する。これが振り角による歩度変化の一つの 原因となり，また動きに伴う摩擦がエネルギ消耗の一 つの原因にもなっている．更に長期間使用すると緩急 針とひげとの接点附近が明らかに摩耗しているのが見 られる。このように緩急針を用いる事にはいろいろの 欠点が伴うが取技いが便利であるため多くの時計に使 用されている。

㭙計の歩度はひげの脍さとテンプの慣性とで定まる から，テンプの慣性を変えて歩度を調整する事もでき るはずである。パテク社のジャイロマクスはこのねら いで作られたもので，天輸の周辺に切久きのついたピ ンを偶数佪植えて方き，切欠きの向きを变えてテンプ の慣性を加減するものである，切欠きを外側に向计た 時が慣性最小で時計は進み，内側に向けるとおくれ る.一対のピンをそれぞれ $180^{\circ}$ 回転すると日差にし て18 秒変化するから十分こまか心調節ができる。な おこの記事の英交表題は War on the curb-pin regulator で，直訳すれば緩急針の問題への戦いである。

〔神保泰雄]

\subsection{3 .2}

〔620〕光てこを用いた高感度記録〔R. Jones \& J. Richards, J. Sci. Instr., 1959-2, Vol. 36, No. 2, p. 90〜94, 図 7]光てこと光電池とを組合方せて $10^{-10}$ ラジアンまで検出できる高感度記録装置を作っ た、鏡とレンズ系により第一格子の像を第二格子の上 に作る. 二つの格子がちょうど一致すると光は全部通 過し,格子幅だけずれると光は全部しや断される.第二 格子は上下二つに分かれており，上方を光が全部通 過する時下方は完全にしゃ断されるるうに作られてい る. 鏡の静止の位置において第二格子の上下を通過す る光量唯等しくなるように調節しておけば，鏡の回転 により一方の光量が増し他方各減る。これを二つの光 電池で受けてブリッジ回路に入れ増幅記録するのであ る. 感度は格子幅,光源電球の明るさ,鏡の大きさに左 右され，光源には $4 \mathrm{~V}, 3.2 \mathrm{~W}$ の電球，鏡には $2 \mathrm{~mm}^{2}$ の物を用いて $10^{-10}$ ラジアンの感度を得た。感度の上 限はノイズの大きさで定まるが，著者はノイズを上記 の量の約 1/10 におさえる事に成功した。スリットの 幅は $1 \mathrm{~cm}$ あたり 5〜70唯適当で，あまり細くすると回 折の影響が現われる。

[神保 永雄]

\section{$620.179 .52: 621.9 .011$}

[621]切削性判定の新法についての研究 [M. Busching, Maschinenmarkt, 1959-1-6, Jg. 65, Ht. 2, S. 28〜36, 図 23]切削試験を行った之き，同一溶 融口ットに属する金属材料塊にもかかわらず，その 切削性唯しく不同で, 測定数值がはげしく散ること はしばしば目撃されるところであって，筆者はここに 疑を抱きこれを解明するために，おびただしい奏験を 